\title{
WISATA KULINER KOPA (PENDEKATAN DESAIN ARSITEKTUR MODERN TROPIS)
}

\author{
Henry Soleman Raubaba*1, Anton Topan ${ }^{1}$, Alexander Matius Reyaan ${ }^{1}$ \\ ${ }^{1}$ Teknik Arsitektur, Fakultas Teknik, Universitas Musamus, Merauke \\ J1. Kamizaun Mopah Lama Merauke, Papua, 99611 \\ *Email : henry_soleman@unmus.ac.id
}

\begin{abstract}
Abstrak
Kabupaten Merauke memiliki beberapa tempat rekreasi diantaranya; Taman Nasional wasur, Kawasan Wisata Perbatasan RI-PNG di Sota, Lotus Garden, Kolam Parako, Kawasan Niaga Semesta, Taman Festival Kuliner PMI. Tetapi tempattempat rekreasi tersebut belum ada yang dikemas secara terpadu yang terdiri dari tempat makan, tempat bersantai, tempat bermain anak. Untuk mendukung perkembangan Kota Merauke perlu diadakan fasilitas Pusat Kuliner yang lebih representatif. Tujuan penelitian ini yaitu merencanakan dan merancang Wisata Kuliner Kopa dengan tampilan visual yang menarik ditunjang dengan tapak yang aksesibel dengan Pendekatan desain arsitektur Modern Tropis. Metode yang digunakan dalam penelitian ini adalah metode penelitian deskriptif, dilakukan dengan cara mengumpulkan data berupa wawancara pada pihak pengelola Kolam Parako dan dokumentasi langsung terhadap objek yang diteliti. Hasil dari data yang diperoleh digunakan sebagai acuan menentukan jenis kebutuhan ruang serta jenis kegiatan.Perancangan Wisata Kuliner Kopa dengan luas lahan 3,7 Ha dibagi menjadi 4 bagian yaitu; (1) Fasilitas Pengelola, (2) Fasilitas Kuliner (3) Fasilitas Kolam Pemandian (4) Fasilitas Penunjang. Pendekatan arsitektur modern tropis yang diterapkan diantaranya; optimalisasi penghawaan dan pencahaan alami, penggunaan material modern seperti penggunaan penutup atap zincalum, penggunaan dinding partisi GRC.
\end{abstract}

\begin{abstract}
Merauke Regency has several recreational places including; Wasur National Park, RI-PNG Border Tourism Area in Sota, Lotus Garden, Kolam Parako, Semesta Commercial Area, PMI Culinary Festival Park. But there are no recreational places that are packaged in an integrated manner which consists of a place to eat, a place to relax, a place to play children. To support the development of Merauke City, a more representative Culinary Center facility needs to be held. The purpose of this study is to plan and design Kopa Culinary Tourism with an attractive visual appearance supported by a site that is accessible to the Modern Tropical architectural design approach. The method used in this research is descriptive research method, carried out by collecting data in the form of interviews with Kolam Parako managers and direct documentation of the object under study. The results of the data obtained are used as a reference to determine the type of space requirements and types of activities. The design of Kopa Culinary Tourism with a land area of $5 \mathrm{Ha}$ is divided into 4 parts, namely; (1) Managing Facilities, (2) Culinary Facilities (3) Bathing Facilities (4) Supporting Facilities. Modern tropical architecture approaches are applied including; optimization of natural ventilation and lighting, use of modern materials such as the use of zincalum roof cover, use of GRC partition walls.
\end{abstract}

Kata Kunci: Wisata Kuliner., Kolam Parako Merauke.,Arsitektur Modern Tropis.

\section{Pendahuluan}

Indonesia memiliki banyak potensi sumber daya alam yang belum dikembangkan dan dikelola secara maksimal, oleh karena itu perlu adanya pengelolaan dan pengembangan pada potensi alam tersebut. Salah satu sektor yang paling mendukung dalam mengembangkan dan mengelola potensi alam tersebut adalah sektor pariwisata. Untuk lebih memantapkan pertumbuhan sektor pariwisata dalam rangka mendukung pencapaian sasaran pengembangan potensi alam, perlu diupayakan pengembangan produk-produk yang mempunyai keterkaitan dengan sektor pariwisata. Salah satu produk atau potensi yang dimiliki Indonesia yang mendukung dan berkaitan erat dengan sektor pariwisata adalah produk atau potensi kuliner Indonesia yang sangat beragam. 
Indonesia merupakan negara yang kaya akan berbagai macam kuliner. Kuliner yang ada di Indonesia berkembang sesuai dengan budaya yang ada pada masyarakat Indonesia sendiri[1]. Pengembangan wisata kuliner berkaitan erat dengan pelestarian nilai-nilai kepribadian dan pengembangan budaya bangsa. Sejalan dengan pemanfaatan seluruh potensi keindahan dan kekayaan alam pengelolaan dan pemanfaatan potensi wisata kuliner yang dimiliki daerah juga dikelola oleh masing-masing daerah. Begitu juga halnya dengan Kabupaten Merauke, dimana Kabupaten Merauke memiliki banyak potensi dan sumber daya alam yang dapat dikembangkan sebagai daya tarik wisata kuliner.

Kabupaten Merauke memiliki banyak potensi baik sumber daya alam maupun keberagaman kuliner yang dapat digunakan sebagai daya tarik wisata, diantaranya yaitu wisata alam Biras, Lotus Garden, Kolam Parako, kawasan perbatasan RIPNG di Sota dan wisata kuliner Warung Joglo Semangga, kompleks Kompleks Niaga Semesta (KNS) di Jalan Seringgu, taman festival kuliner Palang Merah Indonesia (PMI), kawasan kaki lima sepanjang Jalan Ahmad Yani dan Jalan Aru. Keberadaan tempat-tempat wisata ini merupakan cikal bakal dalam pengembangan wisata alam dan wisata kuliner.

Kolam Parako atau yang lebih dikenal oleh masyarakat Merauke dengan sebutan Kopa merupakan salah satu kawasan wisata yang menyediakan beberapa fasilitas seperti tempat pemancingan, tempat pemandian dan gazebo untuk tempat bersantai bagi masyarakat Merauke. Masyarakat yang datang ke Kopa memiliki tujuan yang sangat beragam diantaranya ada yang ingin berenang, merayakan hari istimewa bersama keluarga dan teman, bahkan ada yang hanya sekedar datang untuk menikmati suasana alam. Namun potensi wisata alam Kopa ini tidak didukung dengan potensi kuliner yang ada di Merauke dan belum dikemas secara menarik. Oleh karena itu diharapkan kedepannya tempat wisata Kopa ini dapat dikembangkan secara optimal seperti dengan menambahkan wadah atau fasilitas kuliner dengan tampilan yang menarik dan mudah diakses, sehingga dapat mengangkat citra Kabupaten Merauke sebagai tujuan wisata wisata kuliner.
Perancangan "WisataKulinerKopa" ditujukan sebagai salah satu destinasi wisata di Kota Merauke sekaligus sebagai sebuah wadah yang menyediakan tempat kuliner.Acuan perancangan dititik beratkan pada tampilan bangunan dengan penggunaan bahan material yang modern seperti material pabrikasi sehingga memberi kesan visual yang modern dan menarik.Selain itu ditunjang aksesibilitas di dalam tapak dari satu fasilitas ke fasilitas yang lain dan dipadukan dengan pemanfaatan potensi site yang masih alami karena dikelilingi oleh hutan sebagai penghawaan alamidan ruang terbuka sebagai pencahayaan alami sehingga menjadi sebuah wadah wisata dan kuliner yang diharapkan dapat menarik wisatawan lokal dan mancanegara. Pendekatan desain arsitektur modern tropis diharapkan dapat menjawab permasalahan dalam perancangan"Wisata Kuliner Kopa”.

\section{Tinjauan Pustaka}

Seiring dunia kuliner kini mulai berkembang, kompetisi di antara tempat tujuan wisata, kebudayaan lokal menjadi hal yang berharga sebagai produk dan aktivitas untuk menarik turis, khususnya dalam bidang kuliner. Berikut peran penting dalam industri wisata kuliner.

- Menjadi pusat pengalaman berwisata bagi wisatawan. Dari sudut pandang wisatawan, makanan dengan identitas lokal setara dengan perjalanan mengelilingi museum dan monumen seperti pada kebiasaan wisatawan.

- Menjadi pembentuk identitas baru kepada masyarakat era pasca modernsebagai elemen dari identitas dan representasi budaya lokal.

- Sebagai produk wisata budaya kreatif yang bisa lebih memperkenalkanberbagaimakanan/kuliner dariberbagai daerah di nusantara.

\subsection{Arsitektur Modern}

Arsitektur modern adalah suatu istilah yang diberikan kepada sejumlah bangunan dengan gaya karakteristik serupa, yang mengutamakan kesederhanaan bentuk dan menghapus segala macam ornamen. Pertama muncul pada sekitar tahun 1900. Pada tahun 1940 gaya ini telah diperkuat dan dikenali dengan gaya internasional 
[2].Berikut ini adalah ciri-ciri dari arsitektur modern :

- Satu gaya internasional atau tanpa gaya.

- Bentuk tertentu, fungsional, bentuk mengikuti fungsi.

- Semakin sederhana merupakan nilai tambah terhadap arsitektur modern.

- Tanpa ornamen.

- Penekanan perancangan pada space, maka desain menjadi polos, simpel, bidang-bidang kaca lebar.

\subsection{ArsitekturTropis}

Arsitektur tropis merupakan salah satu cabang yang mempelajari tentang arsitektur yang berorientasi pada iklim dan cuaca. Bangunan dengan desain arsitektur tropis memiliki ciri khas atau karakter menyesuaikan dengan iklim tropis. Dengan adanya perkembangan konsep dan teknologi, maka bangunan dengan bentuk modern atau hi-tech disebut juga bangunan tropis, hal ini diatasi dengan sistem sirkulasi udara, view, bukaan, ventilasi dan orientasi bangunan serta penggunaan material modern tanpa merusak lingkungan[3]. Desain dengan konsep bangunan arsitektur tropis modern selalu bertitik tolak dengan memperhatikan situasi dan kondisi dimana bangunan tersebut akan dibangun. Selain itu konsep desain tidak hanya berpengaruh pada bangunan sebagai sasaran, akan tetapi konsep arsitektur tropis modern juga dibentuk oleh penataan lansekap sebagai pendukung.

Beberapa ciri desain dengan konsep bangunan tropis modern adalah[3]:

- Konsep bangunan tropis modern memperhatikan kondisi dan situasi dimana bangunan tersebut akan dibangun. Konsep desain berpengaruh dalam membuat fasade pada bangunan, pengaturan tata ruang maupun lansekap.

- Penggunaan material yang ramah terhadap lingkungan.

- Finishing pada fasad bangunan menggunakan kaca yangmemberikan kesan modern, terbuka, dan hangat dengan penerapan elemen pendukung seperti sunshading sebagai filtrasi cahaya yang langsung ke dalam bangunan.

\section{Metode Penelitian}

Metode penelitian yang digunakan dalampenelitianiniadalahmetodepenelitiandeskript if. Metode penelitiandeskriptif merupakan suatu metode dalam meneliti status sekelompok manusia, suatu objek, suatu set kondisi, suatu sistem pemikiran ataupun suatu kelas peristiwa pada masa sekarang. Tujuan dari penelitian deskriptif ini adalah untuk membuat deskripsi, gambaran, atau lukisan secara sistematis, faktual dan akurat mengenai fakta-fakta, sifat-sifat serta hubungan antar fenomena yang diselidiki[4].Teknik Pengumpulan data dalam kegiatan penelitian sangatlah penting karena berkaitan dengan tersedianya data yang dibutuhkan untuk menjawab permasalahan dalam penelitian, sehingga dapat membuat kesimpulan yang tepat.

Lokasi tapak yang digunakan untuk perancangan Wisata Kuliner Kopa ini merupakan eksisting tapak Kopa sendiri yang memiliki tata guna lahan sebagai wilayah BWK hutan pantai hijau[5]. Lokasitapakberada di kelurahanRimba Jaya denganluaskawasanmencapai $\pm 3,7 \mathrm{Ha}$.

Batas-batas wilayah bandara mopah antara lain :

- Sebelah Utara: Kel. Kelapa Lima

- Sebelah Selatan: Kel. Rimba Jaya

- Sebelah Timur: Kel. Rimba Jaya

- Sebelah Barat: Kel. Bambu Pemali

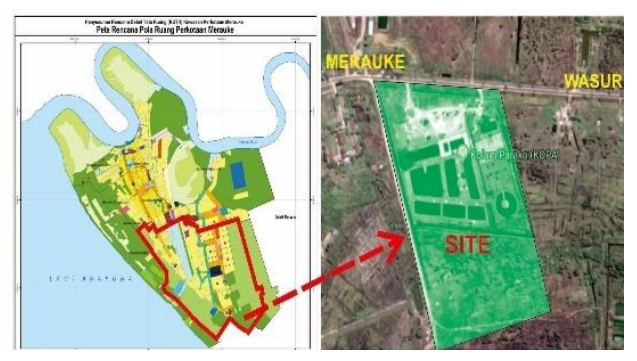

Gambar 1. Letak Tapak

\section{Hasil dan Pembahasan}

4.1 Besaran Bangunan 
Tabel 1.Rekapitulasi Besaran Ruang

\begin{tabular}{c|l|c}
\hline No. & \multicolumn{1}{|c|}{ KebutuhanRuang } & Luas \\
\hline 1 & FasilitasPengelola & $312 \mathrm{~m}^{2}$ \\
2 & FasilitasKuliner & $1.617 \mathrm{~m}^{2}$ \\
3 & FasilitasKolam Pemandian & $527,96 \mathrm{~m}^{2}$ \\
4 & FasilitasPendukung & $152,64 \mathrm{~m}^{2}$ \\
5 & Parkiran & $4.620 \mathrm{~m}^{2}$ \\
\hline
\end{tabular}

Dalam RTRW Kota Merauke,Blok Regional berada di kelas Koefisien Dasar Bangunan (KDB) menengah-bawah (20\%-50\%), mengingat kawasan ini merupakan kawasan konservasi yang harus diminimalkan pembangunan didalamnya[6], maka digunakan $20 \%$ untuk KDB dan $80 \%$ untuk Open Space (OS). Perbandingan luasan 20\% : $80 \%$ Open Space $(\mathrm{OS})=80 / 20 \times 7,230=28,920$ $\mathrm{m}^{2}$. Maka luas tapak yang dibutuhkan : Tapak terbangun $=7,230 \mathrm{~m}^{2}$. Tapak yang tidak terbangun $(\mathrm{OS})=28,920 \mathrm{~m}^{2}$. Total luas tapak= $36,150 \mathrm{~m}^{2}$

Luas tapak yang dibutuhkan untuk Perancangan Wisata Kuliner Kopa adalah seluas $36,150 \mathrm{~m}^{2}$ sedangkan luas tapak yang tersedia adalah 3,7 Ha.Dengan demikian luas tapak yang tersedia dapat mengakomodasi kebutuhan luas tapak yang direncanakan.

\subsection{Lokasi Tapak}

Tapak terletak diantara Jalan Trans Irian. Penentuanlokasididasarkanpadabeberapapertimba nganberikut:

- Pencapaian tapak mudah dijangkau

- Memiliki jaringan utilitas kota yang baik

- Memiliki akses jalur transportasi darat yang baik

- Lokasi tapak strategis dengan roda perekonomian dan pemerintahan kota

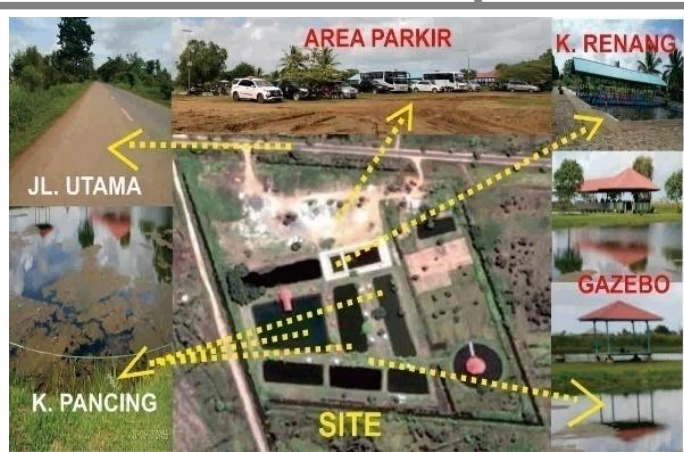

Gambar 2. Potensi Tapak

\subsection{Pencapaian}

Pencapaian ke tapak dapat ditempuh dengan mudah melalui jalur darat yang dapat dilalui dari arah JalanTrans-Irian.

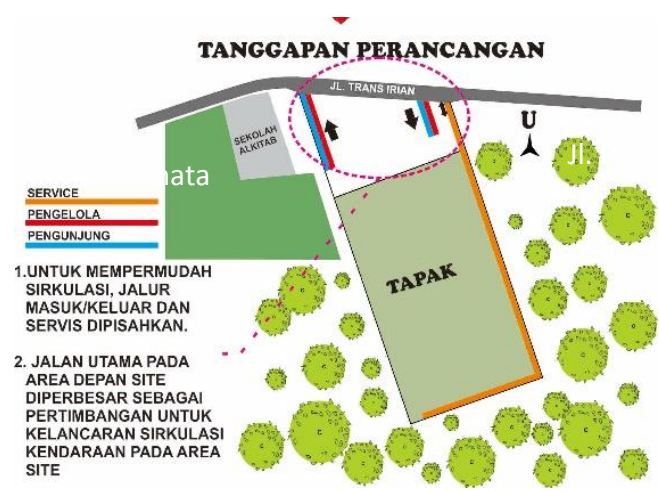

Gambar 3. LokasiTapak

\subsection{View Ke Tapak}

Untuk mendapatkan view yang baik makaperlu diperhatikan semua faktor yang berhubungan dengan view serta kondisi bangunan/tapak di sekitarnya, hal ini diperhatikan agar jarak pandang dan tinggi bangunan sedapat mungkin dapat dilihat dari segala arah atau terlihat dengan mudah. 


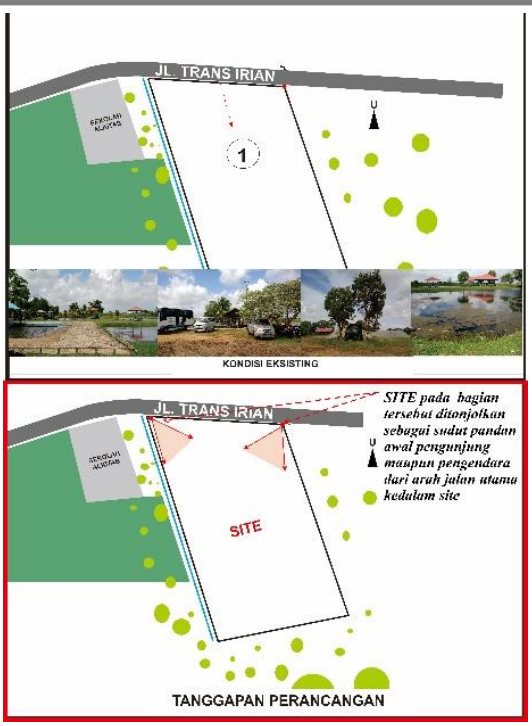

Gambar 4. View keDalamTapak

\subsection{Penzonaan}

Perencanaan Wisata Kuliner Kopa adalah perancangan sebuah kawasan dengan massa banyak. Adapun penzoningan pada tapak dibedakan atas jenis aktifitas dan fungsi tiap-tiap bangunan.

- Zona publik, merupakan area yang dapat dijangkau oleh umum. Zona publik meliputi area parkiran.

- Zona privat, merupakan area yang membutuhkan ketenangan dan kenyamanan agar aktifitas pelakunya dapat terkontrol dengan mudah. Zona privat meliputi, kantor pengelola dan kantor administrasi.

- Zona semi privat, merupakan area yang memiliki aktifitas terbatas dan dapat dijangkau oleh umum. Zona semi privat meliputi area makan pengunjung (outdorindor), gazebo, area/retailkuliner, kolam pemandian, taman dan area bermain anak.

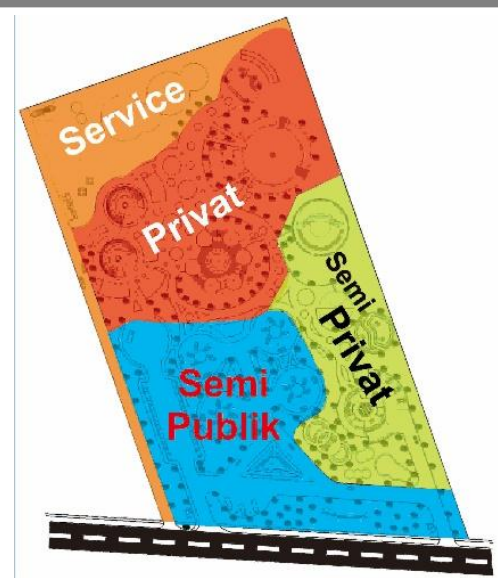

Gambar 5. Penzonaan

\subsection{Struktur}

Strukturbangunanterdiridaritigabagian, diantaranya: sub structuremerupakanstrukturbagianbawahbanguna nataupondasi, mid structureadalahstrukturbagiantengahbangunanatau dinding, sertaupperstructureadalahstrukturbagianatasbangu nanatauatap.

- Struktur pondasi

Jenispondasi yang digunakanadalahpondasifootplatdanpondasim enerus.
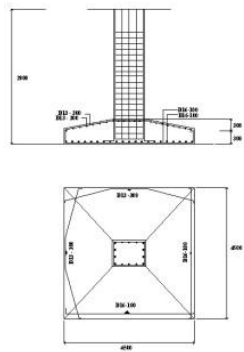

Gambar 6. StrukturPondasi

- Struktur rangka dan dinding

Struktur rangka bangunan menggunakan struktur kolom beton bertulang. Struktur dinding menggunakan dinding bata yang dilapisi material allumunium composite dan juga menggunakan dinding kaca. Untuk dinding penyeka truang di dalam menggunakan dinding partisi dari material Glassfibre Reinforced Cement(GRC) denganrangkabesihollow. 


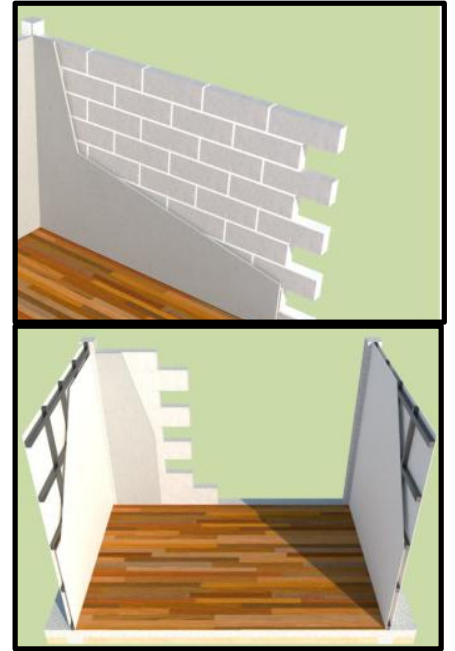

Gambar 7. StrukturRangkadanDinding

- Struktur atap

Strukturrangkaatap

digunakanberuparangka

ringandenganpenutupatapzincalume.

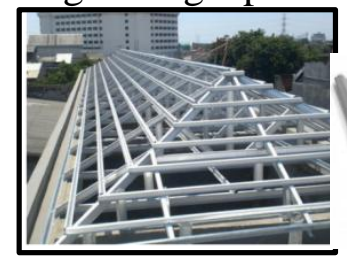

yang

baja

Gambar 8. StrukturAtap

\subsection{Utilitas}

- $\quad$ Sistem jaringan listrik

Terdapat 3 sumber listrik yang digunakan pada Wisata Kuliner Kopa, yakni sumber listrik utama yang berasal dari jaringan Perusahaan Listrik Negara (PLN), sumber listrik cadangan yang berasal dari generator set (genset) yang digunakan apabila sumber listrik utama PLN mengalami gangguan/kemacetan dan sumber listrik yang berasal dari energi surya atau photovoltaic yang digunakan khusus untuk penerangan pada akses jalan dalam tapak. Instalasi dalam gedung dibagi atas 2 bagian yaitu instalasi untuk penerangan dan instalasi untuk power(ACdan pompa), sedangkan untuk jenis lampu yang digunakan adalah lampu hemat energi.

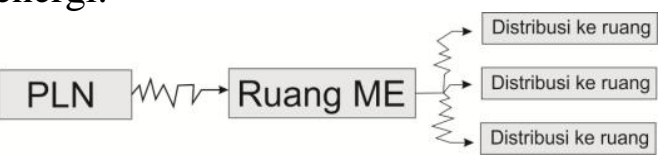

Gambar 9. Sistem Jaringan Listrik

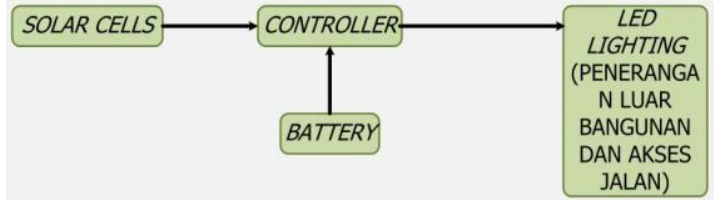

Gambar 10.

Sistem Jaringan Listrik Photovoltaic

- Sistem pembuangan sampah

Sampah dibedakan menjadi sampah organik dan sampah anorganik.

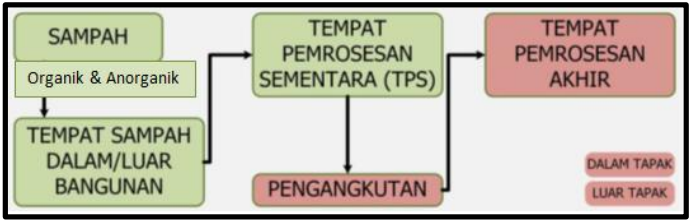

Gambar 11.

SistemPembuanganSampah/LimbahPadat

- Sistem pemadam kebakaran

Sistem pencegahan dan pemadam kebakaran pada terminal meliputi :

$>$ Pencegahan pasif :

Berupa tangga kebakaran, koridor (lebar minimum yang dibutuhkan $1,8 \mathrm{~m}$ ), penerangan darurat, elemen-elemen konstruksi seperti dinding, kolom, dan lantai yang dapat menahan api selama 2 jam.

Pencegahan aktif :

Menggunakan alat-alat diantaranya : fire exitinguisher, hydrant,sprinkler, dan fire alarm.

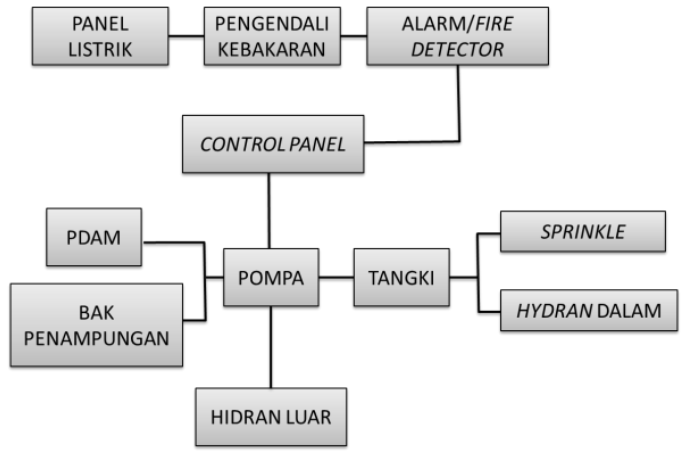

Gambar 12. Sistem Pemadam Kebakaran 


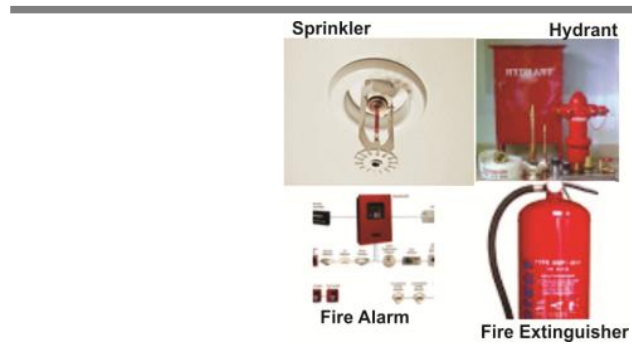

Gambar 13.

\section{Alat Pemadam Kebakaran}

- Penangkal petir

Penangkal petir yang digunakan pada perancangan Wisata Kuliner Kopa adalah penangkal petir elektrostatis dengan jangkauan luasmaksimal $150 \mathrm{~m}$, praktis, serta mudah dan murah dalam pemasangan dan perawatannya.

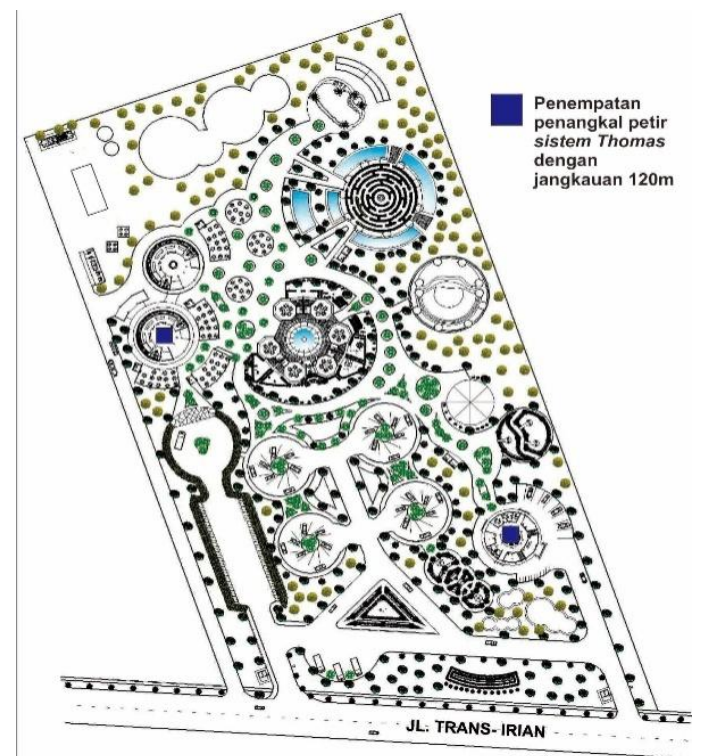

Gambar 14. Penempatan Penangkal Petir

- $\quad$ Sistem jaringan air bersih

Sumber air bersih diambil dari sumur tanah dan PDAM yang disedot melalui pompa kemudian ditampung pada bak penampungan untuk didistribusikan keruang-ruang.

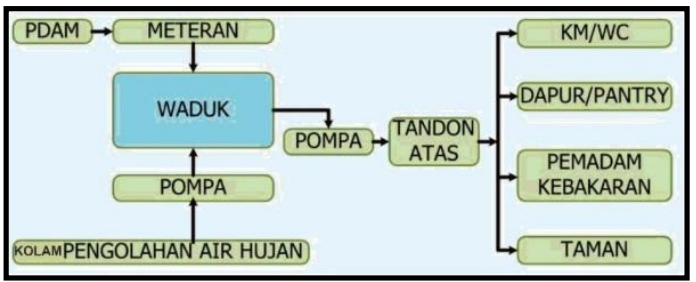

Gambar 15. Alur Distribusi Air Bersih

\section{- Sistem pengolahan air hujan}

Air hujan tidak langsung dibuang, melainkan diolah kembali untuk kebutuhan air pada tapak. Sistem pengolahan air hujan dijelaskan pada gambar berikut:

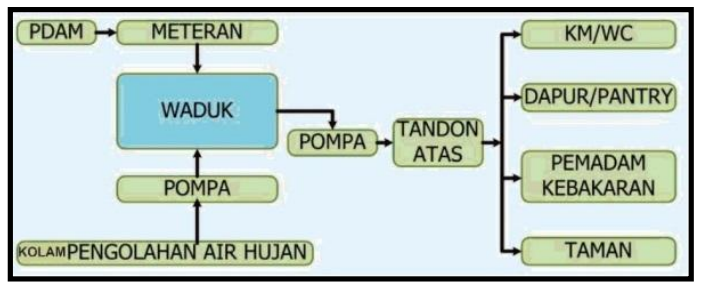

Gambar 16. SistemPengolahan Air Hujan

4.8 Hasil Perancangan

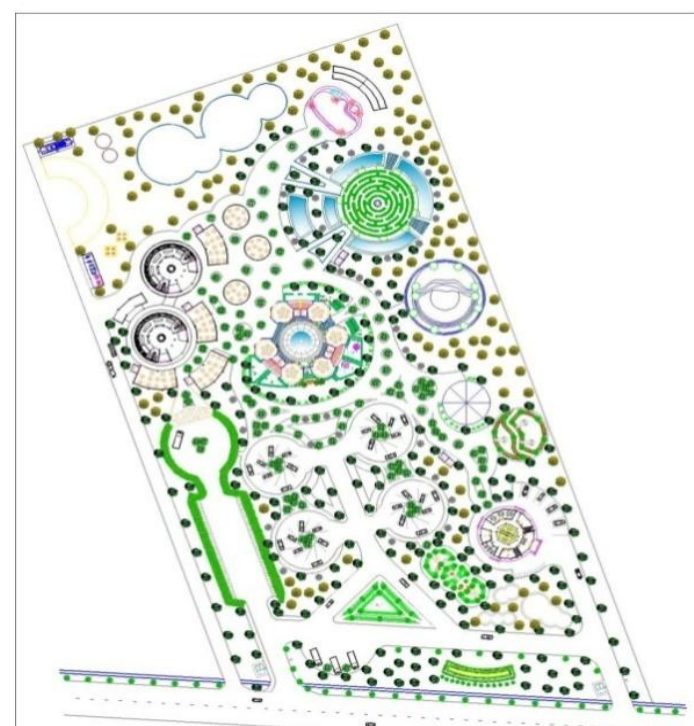

Gambar 17. Site Plan
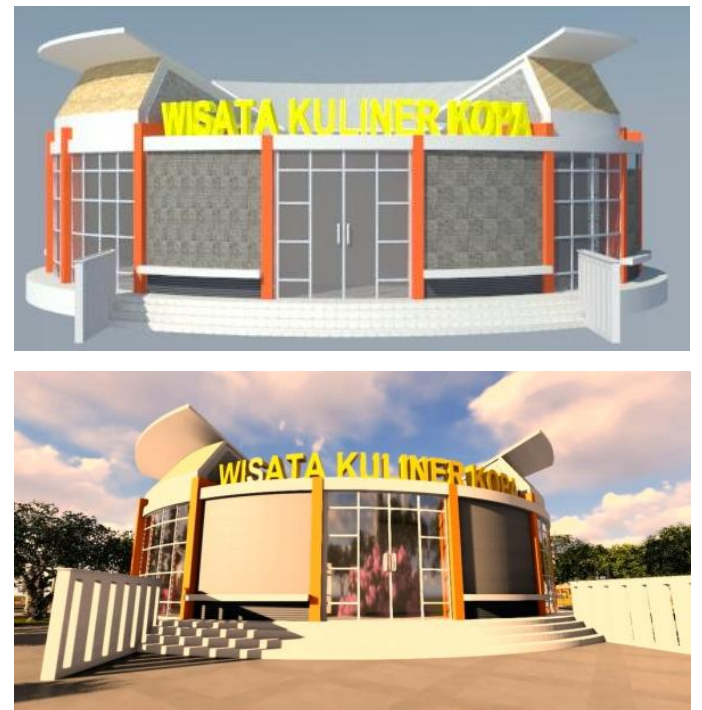

Gambar 18. Bangunan Pengelola dan Administrasi 


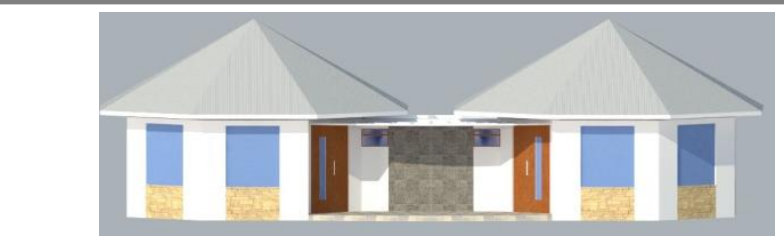

Gambar19. RuangMakanIndoor

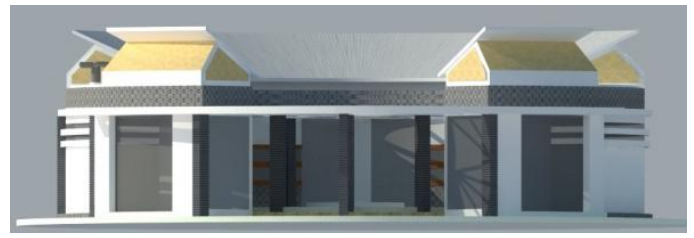

Gambar 20. Dapur

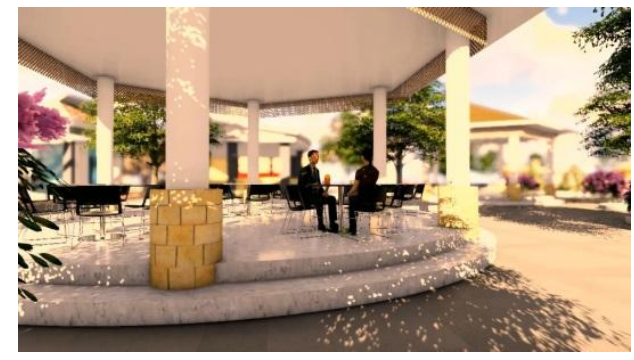

Gambar 21. RuangMakanOutdoor

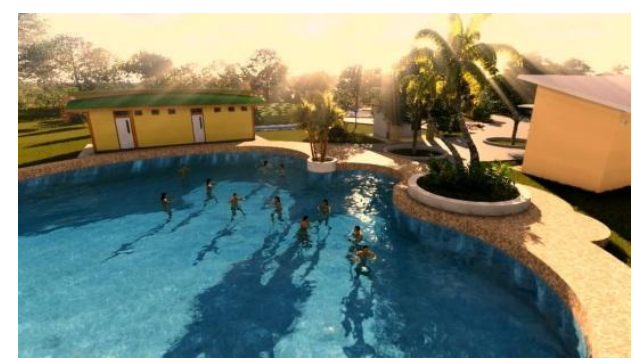

Gambar 22. KolamPemandian

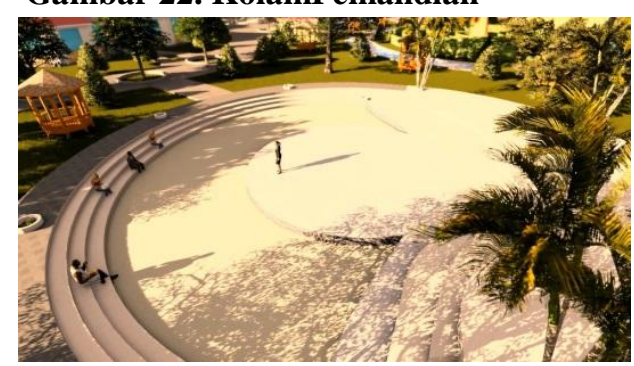

Gambar23. Conser Hall

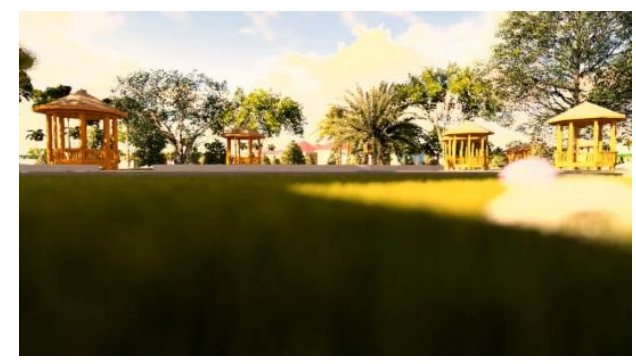

Gambar 24. Gasebo

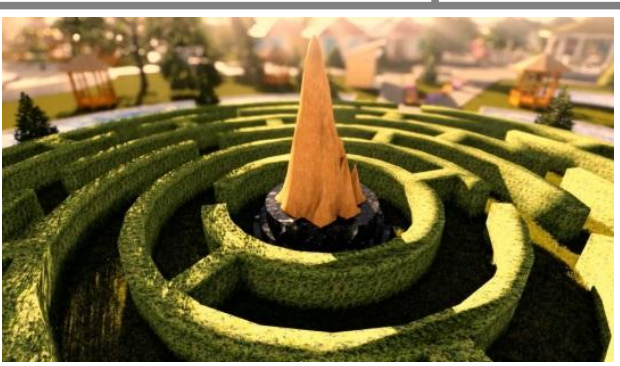

Gambar25. Taman Bermaindan Labirin

\section{Penutup}

5.1 Kesimpulan

- Tapak berada di Kelurahan RimbaJaya dengan luas kawasan mencapai \pm 3,7 Ha.Lokasi tapak memenuhi kebutuhan lahan dan telah dilengkapi dengan utilitas kota serta mudah dijangkau. Penataan bangunan pada tapak didasarkan pada jenis aktifitasnya, hal ini untuk mempermudah pengunjung dalam mencapai setiap fasilitas sesuai dengan jenis kegiatan yang akan dilakukan.

- Wisata Kuliner Kopa merupakan suatu fasilitas yang dirancang dengan tujuan untuk mendukung kegiatan kuliner di Kabupaten Merauke yang digabungkan dengan unsur wisata/rekreasi. Fasilitas yang dirancang (baik bangunan maupun tapak/ruang terbuka) terbagi menjadi 4 bagian diantaranya; fasilitas pengelola (kantor pengelola), fasilitas kuliner (area makan in-door dan outdoor), fasilitas kolam pemandian (kolam renang), dan fasilitas pendukung (taman, conser hall, gazebo). Untuk mendapatkan tapak yang aksesibel, maka dalam perancangan diterapkan beberapa hal antara lain; pencapaian ke dalam dan ke luar tapak dipisahkan untuk pengunjung dan pengelola (servis) untuk mendukung kelancaran sirkulasi dan jangkauan ke dalam fasilitas tapak, penataan massa bangunan di dalam tapak yang mendukung akses antar bangunan.

- Pendekatan desain Arsitektur Modern Tropis pada bangunan ditampilkan selaras dengan kondisi tapak yang merupakan area rekreasi 
dan kondisi sekitar tapak yang masih alami (hutan). Hal ini dihadirkan dari tampilan bangunan yang menggunakan semaksimal mungkin bukaan sehingga memanfaatkan penghawaan dan pencahayaan alami ke dalam bangunan, penggunaan material yang dibuat selaras dengan lingkungan sekitarnya dan dipadukan dengan beberapa material yang lebih modern contohnya yaitu penggunaan material baja pada kolom bangunan (bangunan pengelola, dapur basah/kering, tempat makan in-door/outdoor), dengan dinding partisi menggunakan papan fiber (GRC) dan rangka dinding dari besi kotak/hollow, material atap bangunan yang mengunakan kuda-kuda baja ringan, dak beton serta finishing lantai menggunakan material keramik.

\subsection{Saran}

- Dengan potensi alam dan keberagaman kuliner yang dimiliki Kabupaten Merauke, diharapkan pemerintah daerah dapat memanfaatkannya sebagai daya tarik dan pengembangan wisata. Selain itu juga menjadi salah satu sumber pemasukan bagi daerah.
- Perancangan Wisata Kuliner Kopa dapat menjadi pertimbangan dalam merencanakan suatu bangunan wisata dan tempat kuliner, bahwa dalam merancang perlu memperhatikan atau menyelaraskan antara bangunan dan lingkungan sekitarnya. Selain itu juga diharapkan proses perancangan ini dapat lebih lanjut dikembangkan untuk kelengkapan sarana dan parsarana lain yang belum tersedia.

\section{Referensi}

[1] Nitisuari, Nawangwulan. 2013. Museum Sejarah Kuliner Tradisional Indonesia, Jurnal Interior DesignVol. 2 No. 1 November 2013.

[2] Tjahyono, Gunawan. 1999. "TeoriArsitektur di Dunia Barat".MakalahPenataranDosenArsitektur.Tidakdipubl ikasikan.

[3]Mutmainah, dkk. 2015. Hotel Resort dengan Pendekatan Arsitektur Tropis Modern di Kawasan Wisata Malino Kabupaten Gowa. Jurnal Nucture Nature.

[4] Nazir, Mohammad. 1988. Metode Penelitian. Jakarta: Ghalia Indonesia.

[5] Dinas Cipta Karya Kabupaten Merauke. 2012.Rencana Tata Ruang Wilayah Kota Merauke. Merauke.

[6] BadanPerencanaan Pembangunan Daerah KabupatenMerauke. 2005. Revisi Tata Ruang Wilayah Kota Merauke 2005-2015. PT. Jakarta Sucofindo. Jakarta. 